\title{
THE IMPACT OF CHANGING ENVIRONMENTAL CONDITIONS ON THE RETENTION OF HEAVY METALS ADSORBED BY PINE BARK
}

\author{
Oleksandr Khokhotva \\ National Technical University of Ukraine "Kyiv Polytechnic Institute", Ukraine
}

\begin{abstract}
Landfills are widely used for the disposal of households' and industrial waste. Liquid landfill effluents contain heavy metals, are toxic to humans and ecosystems and have to be efficiently treated. One treatment option that is becoming popular is the reactive filter technology.

The total efficiency of metal removal by a filter media greatly depends not only on adsorption itself, but also on the metal leaching from the adsorbent. The last parameter, in turn, may be dependant on changing environmental conditions since filters are usually located on open air and flow of contaminated water (landfill leachate, runoff water) has the intermittent nature. A filter material may dry, become frozen or stay wet, depending on a season. Previously adsorbed metals can leach from an adsorbent at the next flash of water, coming to water treatment facilities.

Among others, pine bark has shown a high capacity to adsorb heavy metals from landfill leachates. In this study, pine bark has been pre-treated with urea-solution in order to increase its stability and adsorption properties. Within leaching experiments using either non-treated or pre-treated bark samples no significant influence of the changing environmental conditions on the extent of metal leaching was observed, though in most cases, metal leaching from wet bark samples exposed to freezing was somewhat higher. $\mathrm{Zn}$ leaching was the highest and $\mathrm{Cu}$ leaching the lowest for both NTB and UTB samples. The metal leaching from non-treated bark was several-fold higher compared to urea-treated bark. Possible mechanisms of barkurea interactions and reasons for enhanced metals adsorption by urea-modified bark are discussed.
\end{abstract}

\section{KEY WORDS}

Pine bark; Urea; Heavy metals; Adsorption; Leaching.

\section{INTRODUCTION}

Despite many drawbacks, landfills are still widely used for the disposal of households' and industrial waste. Liquid landfill effluents are toxic for the environment and have to be efficiently treated.

A lot of low-cost adsorbents, such as natural zeolite, blast furnace slag, fly ash, peat $[1,2]$ are proposed for application on landfill leachate treatment facilities. These filter materials were extensively tested in laboratories and showed high efficiency for metal adsorption. Pine bark has been shown to be a low cost sorbent which has a high capacity to adsorb heavy metals, and is readily available in the Nordic countries $[2,3]$. Treatment of pine bark with $5 \%$-urea 
solution significantly promotes heavy metal adsorption and greatly reduces the desorption of adsorbed metals [4].

An important factor, greatly influencing the total efficiency of metal removal from effluents, is the retention capacity of a filter material, in other words - to what extent an adsorbent is capable of retaining already adsorbed metals. Chemical desorption, using acids [3, 5], chelating agents [6] and biological leaching [7] is mostly presented in the published papers. The leaching of adsorbed metals into water is almost not investigated.

Filter materials, used on-site in real scale applications are exposed to different changing environmental conditions since they are located on open air. Flow of contaminated water (landfill leachate, runoff water) is not constant in time. After some operation period water flow may be interrupted and filter material may dry, become frozen or stay wet, depending on a season. Previously adsorbed metals can leach from an adsorbent at the next flash of water, coming to treatment facilities. The extent of metal leaching may be dependant on the environmental conditions in which filter material stayed. This kind of investigations is rarely present in the papers. The aim of this study was to investigate the influence of environmental conditions on leaching of adsorbed heavy metals from non-treated and urea-treated pine bark

\section{EXPERIMENT SETUP}

Pine bark of the species Pinus sylvestris used in the study was obtained from Zugol AB, Falun, Sweden.

The bark referred to below as UTB (urea-treated bark) was prepared according to the following procedure: $200 \mathrm{~g}$ of bark was treated in four litres of 5\% urea-solution for 24 hours at $\mathrm{pH} 6$ by adjusting the $\mathrm{pH}$ with $1 \% \mathrm{NaOH}$ at regular intervals. Then bark was thoroughly washed with deionised water to remove reaction products and non-reacted chemicals.

The second bark sample labelled as NTB (non-treated bark), was obtained by mixing $200 \mathrm{~g}$ of bark with four litres of deionised water for 24 hours without any $\mathrm{pH}$ control or adjustment. Then both bark suspensions were filtered through a sieve in order to remove very tiny particles and then left at room temperature on a sieve so that excess water may leak out.

Working solution containing $\mathrm{Cu}^{2+}, \mathrm{Ni}^{2+}$ and $\mathrm{Zn}^{2+}$ in amount $10 \mathrm{mg} / \mathrm{l}$ each metal was prepared from the stock solutions of individual sulfate salts of the corresponding metals and synthetic fresh water, prepared as described in [8]. Ten liters of such solution was divided into two equal parts and contacted with wet NTB and UTB bark samples (150 g each) in separate buckets for 24. After that bark samples were filtered trough a paper filter and left alone so that the residues of metal solution could leak out from bark. Wet bark was weighted and moisture content was determined gravimetrically.

Five leaching experiments were conducted in duplicates according to the following schemes:

1) Prior the leaching test bark was kept wet 5 days in closed vessel to avoid bark drying. The resulted leachate was labeled as $\mathrm{W}$;

2) Prior the leaching bark was air-dried for 5 days until constant weight. The resulted leachate was labeled as D;

3) Prior the leaching bark was frozen at $-18^{\circ} \mathrm{C}$ for 5 days. The resulted leachate was labeled as $\mathrm{F}$; 
4) Prior the leaching test a bark sample was air-dried for 5 days until constant weight and then dried bark is frozen at $-18^{\circ} \mathrm{C}$ for 5 days. The resulted leachate was labeled as DF;

5) Prior the leaching test a bark sample is frozen at $-18^{\circ} \mathrm{C}$ for 5 days and then frozen bark is air-dried for 5 days until constant weight. The resulted leachate was labeled as FD.

Each of samples of NTB and UTB (12 g of dry weight) with adsorbed metals was placed into $250 \mathrm{ml}$ Duran bottles and synthetic fresh water was added to a liquid-to-solid ratio in the bottles of 10:1. All bottles put in a rotator, $10 \mathrm{rpm}$, for 24 hours. The solid samples were then separated from the leachate by filtration trough acid washed filter paper and preserved by 0.5 ml super pure concentrated $\mathrm{HNO}_{3}$.

Blank leaching tests were also conducted in duplicates using NTB and UTB bark samples under leaching schemes described above.

Metal content was determined using an atomic absorption spectrophotometer (AAS Vario 6, Analitik Jena) with flame atomization.

Amounts of metal leached from a bark sample after the first leaching were calculated as $\%$ from amount of adsorbed metals with subtracted metal leaching in blank test. Amounts of metal leached from a bark sample after the second leaching (if applicable) were calculated as $\%$ from amount of metals retained by bark after the first leaching.

Nitrogen and carbon content of bark was determined by elemental analysis using a CarloErba NA1500 analyzer at the Department of Limnology, Evolutionary Biology Centre, Uppsala University.

The number of phenolic and carboxylic functional groups was determined in NTB and UTB samples by the classical baryt/calcium acetate method and by the sodium carbonate/hydrogen carbonate acid-base potentiometric titration method $[9,10]$.

\section{RESULTS AND DISCUSSION}

\subsection{Adsorption and leaching of heavy metals}

Adsorption and leaching of the metals were conducted in synthetic fresh water in order to simulate the presence of the most common ions $\left(\mathrm{Na}^{+}, \mathrm{K}^{+}, \mathrm{Ca}^{+}, \mathrm{Mg}^{+}, \mathrm{SO}_{4}^{-2}, \mathrm{Cl}^{-}, \mathrm{HCO}_{3}^{-}\right)$in fresh water and to keep $\mathrm{pH}$ constant.

Adsorption of the studied heavy metals by UTB was up to $30 \%$ higher compared to NTB ( Table 1), confirming earlier results [4].

Leaching of $\mathrm{Cu}$ and $\mathrm{Ni}$ was not detected in blank leachates using flame atomization neither in NTB nor in UTB bark samples. Leaching of Zn was detected only in NTB and was dependent on simulated environmental conditions (wetting, drying or freezing) prior to the leaching test and constituted $2.1 \mu \mathrm{g} / \mathrm{g}$ for wet and frozen bark samples and $3.6 \mu \mathrm{g} / \mathrm{g}$ for dried bark.

Table 1. Specific adsorption of metals by non-treated and urea-treated pine bark. Initial concentration of the metals was $10 \mathrm{mg} / \mathrm{l}$.

\begin{tabular}{|c|c|c|c|c|c|c|}
\hline \multirow{3}{*}{$\begin{array}{l}\text { Bark pre- } \\
\text { treatment }\end{array}$} & \multicolumn{6}{|c|}{ Metal adsorption } \\
\hline & \multicolumn{2}{|c|}{$\mathrm{Cu}$} & \multicolumn{2}{|l|}{$\mathrm{Ni}$} & \multicolumn{2}{|l|}{$\mathrm{Zn}$} \\
\hline & $\mathrm{mg} / \mathrm{g}$ & $\%$ & $\mathrm{mg} / \mathrm{g}$ & $\%$ & $\mathrm{mg} / \mathrm{g}$ & $\%$ \\
\hline NTB & 0.29 & 87.7 & 0.23 & 58.4 & 0.18 & 50.1 \\
\hline UTB & 0.32 & 93.9 & 0.33 & 86.4 & 0.28 & 79.6 \\
\hline
\end{tabular}

NTB - non-treated bark;

UTB - bark treated with 5\% urea-solution 
It is not conclusive that one kind of environmental condition stimulates the leaching of all studied metals more than another (Table 2). No large differences in leaching results could be observed within the experimental set for each metal. Clearly, leaching of heavy metals from UTB was several folds lower compared to leaching from NTB samples, which would result in a much higher total metal removal capacity. For both NTB and UTB, metal leaching was the highest for $\mathrm{Zn}$ and the lowest for $\mathrm{Cu}$ ions.

Leaching of $\mathrm{Cu}$ from NTB was higher in the experiments where bark samples were not exposed to drying (W, F). Processes of aerobic degradation of bark can occur in wet adsorbent, which promotes leaching of DOC (Dissolved Organic Carbon). It has been previously found that among studied metals, adsorption and desorption of $\mathrm{Cu}$ was the most sensitive to the presence of dissolved organic substances with enhanced copper desorption even at a very small DOC concentration [4].

Table 2. Leaching of metals from NTB and UTB depending on the pre-treatment of loaded bark samples.

\begin{tabular}{lllllll}
\hline \multirow{2}{*}{$\begin{array}{l}\text { Leaching } \\
\text { scheme }\end{array}$} & \multicolumn{2}{l}{ Metal leaching, $\%$} & & & Zn & \\
\cline { 2 - 7 } & $\mathrm{Cu}$ & & $\mathrm{Ni}$ & $\mathrm{NTB}$ & $\mathrm{UTB}$ \\
\cline { 2 - 7 } & $\mathrm{NTB}$ & $\mathrm{UTB}$ & $\mathrm{NTB}$ & $\mathrm{UTB}$ & 18.14 & 4.22 \\
\hline $\mathrm{W}$ & 2.04 & 0.12 & 11.94 & 3.11 & 18.15 & 6.77 \\
\hline $\mathrm{D}$ & 1.84 & 0.23 & 12.44 & 5.12 & 19.12 & 5.08 \\
\hline $\mathrm{F}$ & 2.23 & 0.50 & 12.47 & 4.50 & 18.21 & 5.92 \\
\hline $\mathrm{DF}$ & 1.79 & 0.19 & 12.14 & 4.36 & 18.70 & 6.39 \\
\hline FD & 1.98 & 0.35 & 13.61 & 5.27 & & \\
\hline
\end{tabular}

NTB - non-treated bark;

UTB - bark treated with 5\% urea-solution;

$\mathrm{W}$ - bark was kept wet before leaching test;

$\mathrm{D}$ - bark was air-dried before leaching test;

$\mathrm{F}$ - bark was frozen (being in wet condition) before leaching tests;

DF - bark was first dried and then frozen before leaching test;

FD - bark was first frozen (being in wet condition) and then air-dried before leaching test

Freezing of wet bark had the highest impact on metal leaching from NTB samples. This could be due to the fact that, during freezing, water forms ice crystals in bark that damage the porous system and cell walls, thus stimulating the release of DOC into an ambient solution during thawing. This type of DOC previously stayed in bark cells and was not accessible via the normal contact of bark with water. Increased metal leaching due to increased DOC concentration after thawing was also noted by the researchers [11].

The trend for UTB is different since a considerable amount of DOC was removed from the pine bark by urea-solution during the pre-treatment stage. output signal has been studied in the frames of this paper.

\subsection{Mechanisms of urea-bark interaction}

A number of authors have suggested that modification of lignocellulosic materials with urea is primarily associated with polycondensation processes of urea with lignin and some easily 
accessible regions of hemicelluloses. For example, the study [12] proposed that it is the $\mathrm{C}=\mathrm{O}$ groups of lignin that react with urea. The study [13] compared the elemental compositions of lignin and lignin-urea complex and showed that the number of carbonyl groups in the complexes resulting from urea treatment is significantly lower compared to that in initial lignin. He proposed that lignin interacts with urea forming the following bonds:
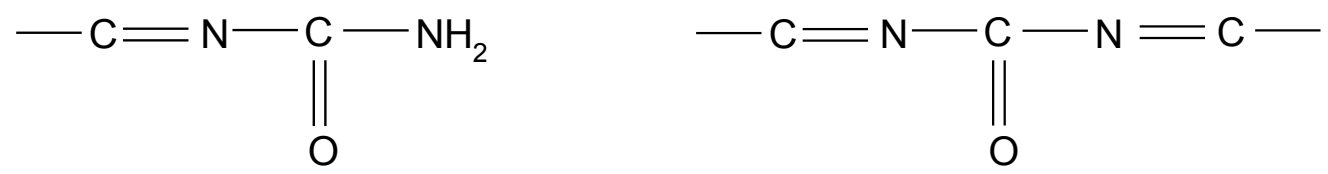

Polycondensation of urea with $-\mathrm{OH}$ and $>\mathrm{C}=\mathrm{O}$ - groups of lignocellulosic material was demonstrated by IR-spectroscopy [14].

In this study nitrogen and carbon content in the pine bark were measured by elemental analysis. The urea-modified pine bark contained $28 \%$ more nitrogen than unmodified bark $(0.326 \%$ compared to $0.417 \%)$ while the carbon content was slightly lower in the treated bark - $50.84 \%$ compared to $49.76 \%$. This suggests that additional nitrogen-containing functional groups were introduced onto the surface of pine bark by treatment with urea solution for $24 \mathrm{~h}$.

Functional analysis of bark samples before and after modification showed that the number of carboxylic active sites decreased by almost three quarters from 0.225 to $0.06 \mathrm{mmol}-\mathrm{eq} / \mathrm{g}$, while the number of phenolic acidic groups remained the same $(0.84 \mathrm{mmol}-\mathrm{eq} / \mathrm{g})$. For the latter analysis both the baryt/calcium acetate method and the sodium carbonate/hydrogencarbonate method gave similar results. Table 3 presents a comparison of the experimentally obtained values of maximum metal adsorption, expressed in mmol-eq/l and ionic $\left(Z^{2} / r\right)$ and covalent $\left(X^{2}{ }_{m} \mathrm{r}\right)$ indexes. $X_{m}$ is the metal ion electronegativity, $Z$ is its formal charge and $r$ is the ionic radius corresponding to the most common coordination number. The covalent index is a measure of the relative importance of covalent interactions compared to ionic interactions for a particular metal. Ionic index is a measure of the metal ion involvement in electrostatic interactions.

As there is a large diversity of functional groups on the surface of pine bark, heavy metals can be taken up through a number of different mechanisms, including ion exchange, chelation with different groups and precipitation. Obviously, both ionic and covalent interactions contribute to the formation of bonds between atoms with unequal electronegativity. The very different ionic and covalent indexes and different maximum adsorptions of the metals considered here suggests that they may interact with the bark surface via different mechanisms. Copper, nickel and zinc all occur in period 4 of the periodic table and of these, zinc has the lowest values of both indexes and thus shows the least adsorption. Lead belongs occurs in period 6 and has the least ability to be involved in ionic interactions, but has the highest covalent index and the highest maximum adsorption, suggesting that lead is mostly adsorbed to bark though covalent interactions with undivided electron pairs of oxygen and nitrogen atoms of the corresponding functional groups. 
Table 3. Dependence of ionic, covalent indexes and amount of metals adsorbed by unmodified and urea-modified pine bark.

\begin{tabular}{lllll}
\hline Metal ion & Ionic index, $\mathrm{z}^{2} / \mathrm{r}$ & Covalent index, $\mathrm{X}_{\mathrm{m}}^{2} \mathrm{r}$ & $\mathrm{q}, \mathrm{mmol}-\mathrm{eq} . / \mathrm{l}$ \\
\cline { 4 - 5 } & & & $\mathrm{NTB}$ & $\mathrm{UTB}$ \\
\hline $\mathrm{Zn}^{2+}$ & 5.33 & 2.16 & 0.1564 & 0.3049 \\
\hline $\mathrm{Cu}^{2+}$ & 5.48 & 2.97 & 0.2366 & 0.3798 \\
\hline $\mathrm{Ni}^{2+}$ & 5.71 & 2.56 & 0.2833 & 0.4002 \\
\hline $\mathrm{Pb}^{2+}$ & 4.26 & 3.28 & 0.65 & 1.005 \\
\hline
\end{tabular}

$X_{m}$ - the metal ion electronegativity;

$Z$ - the metal ion formal charge;

$r$ - the ionic radius corresponding to the most common coordination number.

Nieboer and Richardson (1980) suggested the classification of metals into three groups depending on the ratio of ionic and covalent indexes. Each of the three metal groups has preferred ligands with which they create bonds. All metals in the present paper belong to one group, the borderline group, which shows affinity to a wide range of ligands. Among these preferred ligands are various amines and other nitrogen-containing groups. These nitrogencontaining ligands are not preferred by members of the other two groups.

While carboxyl groups may also function as cation exchangers, amino-containing ligands bind metals mostly by chelation. These processes are also likely to take place in the case of adsorption of heavy metals onto urea-modified pine bark. Chelation, but not cation exchange, appears to be an important mechanism for metal uptake by urea-modified bark because $\mathrm{pH}$ values in treated metal solutions do not drop during adsorption as a result of metal-proton exchange $[16,17]$. The increase in $\mathrm{pH}$ values of the metal solutions during adsorption may be caused by anion exchange processes between anions of salts and $\mathrm{OH}^{-}$groups in bark.

\section{CONCLUSIONS}

Metal leaching from UTB was several times lower than from NTB. No significant influence of changing environmental conditions on the extent of leaching was observed, though in most cases, metal leaching from wet bark samples exposed to freezing was somewhat higher. $\mathrm{Zn}$ leaching was the highest and $\mathrm{Cu}$ leaching the lowest for both NTB and UTB samples.

The interaction of urea with carbonyl and carboxylic groups on the pine bark surface leads to the introduction of nitrogen containing groups onto the bark surface, increasing the number of active adsorption sites capable of forming complexes with adsorbed metals.

\section{ACKNOWLEDGEMENTS}

The authors would like to thank The School of Sustainable Development of Society and Technology, Mälardalen University, for providing laboratory materials and equipment. The Swedish Institute is acknowledged for the financial support, which made it possible to carry the laboratory research. 


\section{REFERENCES}

1. Kietlinska, A., Rehnman, G., 2005. An evaluation of reactive filter media for treating landfill leachate. Chemosphere 61(7), 933-940.

2. Nehrenheim, E., Waara, S., Johansson Westholm, L., 2008. Metal retention on pine bark and blast furnace slag - On-site experiment for treatment of low strength landfill leachate. Bioresource Technology 99(5), 998-1005.

3. Palma, G., Freer, J., Baeza, J., 2003. Removal of metal ions by modified Pinus radiata bark and tannins from water solutions. Water Research 37(20), 4974-4980.

4. Khokhotva, O., S. Waara, 2010. The influence of dissolved organic carbon on sorption of heavy metals on urea-treated pine bark. Journal of Hazardous Materials, 173 (1) 689-696.

5. Al-Asheh, S., Duvnjak, Z., 1997. Sorption of cadmium and other heavy metals by pine bark. Journal of Hazardous Materials 56(1-2), 35-51.

6. Fiol, N., Villaescusa, I., Martinez, M., Miralles, N., Poch, J., Serarols, J., 2006. Sorption of $\mathrm{Pb}(\mathrm{II}), \mathrm{Ni}(\mathrm{II}), \mathrm{Cu}(\mathrm{II})$ and $\mathrm{Cd}(\mathrm{II})$ from aqueous solution by olive stone waste. Separation and Purification Technology 50(1), 132-140.

7. Bosshard, P., Bachofen, R., Brandl, H., 1996. Metal Leaching of Fly Ash from Municipal Waste Incineration by Aspergillus niger. Environmental science \& technology 30(10), 3066-3070.

8. EN ISO 6341:1996 Water quality -- Determination of the inhibition of the mobility of Daphnia magna Straus (Cladocera, Crustacea) -- Acute toxicity test.

9. Gelfand, E.D., Bogomolov, B.D., 1970. Потенциометрическое титрование лигнинов в растворе карбоната натрия. (Potentiometric titration of lignines in sodium carbonate solution). In "Modern research methods in lignin chemistry", Arkhangelsk, pp.79-81. (In Russian).

10. Zakis, G.F., 1987. Функциональный анализ лигнинов и их производных. (Functional analysis of ligines and their derivates). Zinātne, Riga. (In Russian).

11. Kalmykova, Y., Stromvall, A.M., Rauch, S., Morrison, G., 2009. Peat filter performance under changing environmental conditions. Journal of Hazardous Materials 166(1), 389393.

12. Abduazimov, Kh. А., 1973. Получение азотсодержащих производных лигнина (Obtaining of the nitrogen-containing compounds of lignin). Khimiia prirodnyh soedinenij. Issue 4, 20-21. (In Russian).

13. Saipov, Z.K., 1976. О взаимодействии лигнина с мочевиной. (About interaction of lignin with urea). Khimiia drevesiny. Issue 2, 78-80. (In Russian).

14. Bazarnova, N.G, Galochkin, A.I., Krestiannnikov, V.S., 1997. Влияние мочевины на свойства прессованных материалов из древесины, подвергнутой гидротермической обработке. (Influence of urea on properties of pressed hydrothermally treated wood materials). Khimija drevesiny 1(1), 17-21. (In Russian).

15. Nieboer, E. and Richardson, D. H. S., 1980. The replacement of the nondescript term 'heavy metals' by a biologically and chemically significant classification of metal ions. Environmental Pollution (Series B) 1, 3-26.

16. Montes, S., Valero, G., Morales, S., Schmidt, R., 2003. Adsorption capacity of copper of natural and modified Radiata bark pine. Journal of Chilean Chemical Society 48(4), 11 16.

17. Randall, J.M., Garret, V., Bermann, R.L. and Waiss, A.C., 1974. Use of bark to remove heavy metal ions from waste solutions. Forest Products Journal 24(9), 80-84. 